\title{
COMMENT
}

DOI: $10.1057 /$ s41599-018-0114-8

\section{What is 'regeneration' and who needs it?}

Pat Thane ${ }^{1}$

\section{ABSTRACT}

Regeneration is an ambiguous term with diverse meanings. According to the Oxford English Dictionary, to be regenerated is to be 're-born; brought again into existence; formed anew', no doubt an accurate usage but one that is arguably too narrow. More appropriate is another meaning the OED suggests: 'restored to a better state'. Most definitions of regeneration have been driven, over many times and places, by concern about ageing and the desire, at best, to reverse or, at least, to modify its perceived ill-effects. This article considers what we understand by regeneration and who needs it.

\footnotetext{
${ }^{1}$ King's College London, London, UK. Correspondence and requests for materials should be addressed to P.T. (email: pat.thane@kcl.ac.uk)
} 


\section{Introduction}

$s$ several papers in the collection accompanying this article point out, regeneration is an ambiguous term with diverse meanings (Burke, 2017; Clark, 2017; Edwards et al. 2017; Gilleard, 2017; Logan, 2017). According to the Oxford English Dictionary, to be regenerated is to be 're-born; brought again into existence; formed anew', no doubt an accurate usage but too narrow to describe the range of activities discussed here. More appropriate is another meaning the OED suggests: 'restored to a better state'. It describes this as a 'religious use' but it is surely of wider relevance to the many dreams, experiments and speculations discussed in the above-mentioned accompanying essays. Most have been driven, over many times and places, by concern about ageing and the desire, at best, to reverse or, at least, to modify its perceived ill-effects.

\section{Perspectives on regeneration}

As Gilliard suggests this drive has existed over many centuries because in all known societies a certain proportion of people have lived to what their culture defined as 'old age', arousing, for as far in the past as we have records, interest in and concern about change in the ageing body and whether it could be halted, slowed or reversed (Gilleard, 2017). We can best illustrate this by taking age 60 as the lower boundary of old age. This is realistic because, perhaps surprisingly, even in ancient Greece and Rome 60 was often seen as the lower boundary of old age as, widely, it still is: in Greece it was the age at which men were no longer called for military service (Finlay, 1984).

In the UK, as in many other societies, over the past 100 years, most rapidly since the mid- twentieth century, more people have lived longer than ever before (Table 1). In $18814.6 \%$ of the UK population was aged over 65 , in $19317.4 \%$. They now form about $18 \%$, up from $15 \% 30$ years ago and $11 \% 50$ years ago. In 2016 there were 14,910 people aged over 100 in the UK, double the number in 2002 (7750); there were 3642 in 1986. There are now five female to every male centenarians. ${ }^{1}$ Some other countries have aged even more rapidly, notably Japan with over 65,000 centenarians in $2016,87 \%$ female. This number has more than doubled since 2007. Japan has the highest proportion of older people of any country, partly due to its very low birth rate. In most times and places women outlive men for reasons that are uncertain, especially because women tend to be poorer. The gap is narrowing in UK, but it remains.

Statistics of life expectancy need to be handled with care because they are based upon averages which hide wide inequalities. In the UK, and most other countries, there is a significant socio-economic gap in life expectancy. According to the Office of National Statistics (ONS), in England and Wales in 2012-14 boys born in rich Kensington and Chelsea could expect to live to 83.3 years, boys born in poorer Blackpool only to 74.7. Baby girls could expect to live longest in Chiltern, 86.7 years, shortest in poorer Middlesborough, 79.8 years. There are similar gaps in life expectancy at age 65 . Richer people live longer and also remain healthy longer. The ONS reported in 2014-2016 the gap in healthy life expectancy at birth differed by 18.4 years for females and 15.6 years for males across richer and poorer areas of the UK and the disparity has grown in recent decades. ${ }^{2}$ Inner city Glasgow has some of the lowest life and health expectancy figures in the UK.

More people are living longer and more are healthy later in life, but the big inequality gap alerts us to diversity among older people, past and present. It is an age group much stereotyped and generalized about, but it is the largest and most diverse of all conventionally defined age groups, assumed-still- to run from around age 60 to past 100. It includes some of the richest (including Queen Elizabeth II) and the poorest, the extremely frail and marathon runners in their $80 \mathrm{~s}$ and $90 \mathrm{~s}$. Fauja Singh, a Sikh born in India in 1911 who migrated to Britain in 1961 became the first centenarian to compete a marathon, in Canada in 2011. Some older people have good pensions, expensive houses and affluent lifestyles, but Age UK calculated that in April 2016 $14 \%$ of all pensioners, about $1.6 \mathrm{~m}$, were in poverty (with incomes less than $60 \%$ of median income, the official poverty measure) and a similar number on the brink of poverty, with no incomes but their state pensions and other state benefits. ${ }^{3}$ UK state pensions have never provided enough to live on since they started in 1908 and are among the lowest of any high income country. Women are especially at risk of poverty, so are the Pakistani and Bangladeshi communities, all because they have low lifetime incomes. We must take account of cultural diversity in considering ageing in an increasingly multicultural society. Members of minority ethnic groups may suffer poor health due to poverty in early life in their countries of birth. If English is not their first language they may have difficulty accessing health and social services, though the story of Fauja Singh suggests the diversity of all social groups.

Too often these many forms of diversity are overlooked and all people over a certain age stereotyped as similar, often as frail, dependent burdens on younger generations. This overlooks the positive contributions to society of very many older people. In Britain as elsewhere increasing numbers stay longer in paid work, since the fixed retirement age was abolished in 2011; more want to work longer because they still feel fit and active; others because they will have low pensions. Employers are often reluctant to keep them on because they underestimate the capacities of older workers, the importance of their experience and their capacity for further training. That older workers can learn new skills and can be as, or more, efficient than younger workers has been pointed out by industrial psychologists since the 1940s (Thane, 1990), but employers can still be reluctant to believe it. Average retirement ages are gradually rising and pension ages are set to rise in order to stem the cost of pensions as Britain ages. But again the averages disguise great disparities. About $20 \%$ of workers, generally the poorest, cannot work even to the current pension age of 65 due to poor health. ${ }^{4}$

Growing numbers of fit, active older people also make important unpaid contributions to society and the economy. UK government surveys from 2001-2011 showed that about 30\% of over-60s volunteer regularly for voluntary organizations at home and abroad. ${ }^{5}$ Voluntary Service Overseas was established in 1956

Table 1 Estimated average percentages of populations aged 60 and above

- Ancient Rome: 6-8\%

- Medieval Europe: 5-8\%

- England, 17th century: 6-8\%

- France, Spain, England, 18th century: 10\%

Sources: Parkin, 2003; Shahar, 1997; Wrigley et al., 1997. All these studies discuss how these estimates were arrived at and the difficulties. 
to enable young people to volunteer in poorer countries, after school or university. Now, many active retired nurses, doctors, teachers, engineers and others, with vastly greater skills and experience to offer than younger people, do this. In $200828 \%$ of VSO volunteers were over 50 compared with 3\% 20 years before. They now advertise for volunteers up to age 75 , which they would not have dreamed of in 1956.

$65 \%$ of people over 65 regularly help neighbors and friends and are the most likely age group to do so. Many retired people in their $60 \mathrm{~s}$ care for their parents in their $80 \mathrm{~s}$ and $90 \mathrm{~s}$ or for partners or disabled children. The value of their formal volunteering has been estimated at $£ 10$ Billion per annum saved to public social services; the value of informal social care at $£ 34$ Billion. Growing numbers of grandparents help younger people to work by caring for grandchildren, some grandparents giving up their own paid work to do so. In 20101 in 3 working mothers relied on grandparents for childcare and the number is probably growing. Older people also give substantial financial support to their children and grandchildren when they can afford it (Grundy, 2005). It has been estimated that that over-65 s make a net contribution to the UK economy, after deduction of pensions, social services and benefits and health care costs, of $£ 40$ Billion through tax payments, spending power, donations to charities and volunteering. ${ }^{6}$ Collectively older people are much less of a costly burden on the rest of society than is often thought. The figures suggest how many of them are fit and active, not obviously in need of 'regeneration'.

Negative stereotyping of old age as a period of decrepitude requiring regeneration risks persuading some people that they should hide their ageing artificially by methods developed, as Clark describes, since the late nineteenth century, including cosmetics and cosmetic surgery, often still encouraged by those making money from such procedures, sometimes causing damage and deterioration rather than regeneration (Clark, 2017). An alternative is for society to learn to value not denigrate the appearance of ageing, to accept that women with gray hair and wrinkles can be just as effective as TV presenters, for example, as men with gray hair and wrinkles. As Clark illustrates, such discrimination has a long history and there is little sign that it is disappearing.

The growing numbers living and remaining healthy to later ages suggests that 'regeneration', avoidance of the earlier deterioration experienced by past generations, has been occurring, widely, for decades. Of course, what may be happening is delay to the onset of frailty and regeneration may be needed at later ages. Few people escape a period of dependent disability before death and, as we have seen, some people already experience it at earlier ages than others. But how has the visible regeneration of recent decades come about? Can the experience provide lessons in how to extend these benefits to the less fortunate? What has been the role of medical intervention in bringing about the lengthening of life and of healthy life compared with other influences, in particular rising living standards? The ONS suggests that the main drivers of the increasing numbers living past 90 in the UK have been 'improved medical treatments, housing and living standards, nutrition and changes in peoples' smoking habits' and they do not suggest that medical treatments have obviously been more important than the other drivers. They refer also to the decline in heavy manual labor since the 1980s as narrowing the life expectancy gap between men and women. ${ }^{7}$ Preventive measures, such as cutting smoking in public places, and increasing awareness of the importance of exercise and diet, have helped more people stay healthy for longer. However, not everyone responds and if the current obesity epidemic continues-again mainly affecting people on lower incomes-it is questionable whether average life and health expectancy will continue to rise.
This suggests that medicine is not the only or perhaps the most effective route to regeneration. The difficulty is to establish the relative significance of the possible influences. If medical intervention has been important, what forms of intervention? It is difficult to know with any certainty because in higher income countries the improvement in general living standards has occurred at the same time that medicine has improved its capacities, over the past 100 years, and the two are closely linked: richer societies can fund medical research, richer people make most use of medicine. Yet in Japan longer life is regularly ascribed to diet rather than medicine. The basic Japanese diet is healthy and as the country has become richer more people can afford to eat well. Japanese medicine, at least until very recently, was not good at keeping older people active. It is hard to tease out the relative influence of medical and other interventions in recent regeneration.

People who are poor in very early life tend to have poorer health later and generally poorer life chances. This raises the question whether social intervention, income redistribution and improved services for poorer people throughout life, shifts towards greater social and economic equality, would do at least as much as medicine to improve healthy life expectancy, avoiding the need for regenerative interventions into the lives of more people. Such interventions have not been tried in UK consistently for long enough to be sure.

We must also consider that, although medical care can keep many people fit and active, physically and mentally, until later in life, all too often it has not been employed optimally for this purpose. Neglect and discrimination involving older people have a long history in medicine. A survey for the Department of Health in 2009 found that over-65 s received poorer care after suffering a stroke than younger people and poorer mental health care, their problems often being under-diagnosed or mis-diagnosed. Women over 80 had markedly poorer access to investigation and treatment for cancer than women in their $60 \mathrm{~s}^{8}$. Women are still called regularly for screening for breast cancer only up to age 70, despite the fact that breast cancer is more common after age 70 . Recently when there have been cuts to health services, such operations as cataract removal and joint replacement have been first to be suspended because they do not deal with lifethreatening conditions. These are medical interventions in conditions most likely to affect older people, which have transformed many of their lives since they were introduced in the later twentieth century and their capacity to function independently and remain healthy can be severely impeded if they are not provided. These cuts also perpetuate social inequality. Better-off older people can afford to pay for such operations privately; most older people cannot. Also many older people are currently taking up scarce NHS bed space which they no longer need, are stopped from being active, because community services are no longer available to care for them at home. The Equality Act, 2010, implemented 2012, made discrimination in health and social care illegal but there is no strong sign of change. Where existing forms of medical regeneration can be effective to restore people to a better state' it is as important to use them as to research new forms of interventions in ageing.

Biogerontologists, or geroscientists as they are sometimes called, are engaged in exploring the biological processes underlying ageing in the belief that they can learn to intervene in these processes to increase the healthy life span. They generally assume that these interventions will be medical. However a recent Briefing Note by the Nuffield Council on Bioethics raises many of the questions referred to above and indicates how far they still are from achieving effective regeneration. It also suggests caution about some proposed interventions and their implications. ${ }^{9}$ As the Note describes, some experimental drugs can have serious 
side effects, as can the use of hormones and anti-oxidents. Some unproven treatments, such as stem-cell therapy, are too readily and expensively taken up by private clinics, marketed as delivering rejuvenation. It stresses that 'as research in this field progresses, reducing harm to consumers from the use of unscrupulous clinics and retailers will become an increasing challenge' and closer regulation is needed, as it is for the 'cosmetic procedures industry'. In addition to the ethical dangers of uncontrolled use of experimental regeneration procedures, it points out that even effective, undamaging interventions

'are likely to be available only through the private sector initially...leading to an exacerbation of existing health inequalities according to income, socio-economic standing and geography...global health inequalities present particular challenges in this context, given that the citizens of some countries still have low life expectancies owing to poor sanitation, nutrition and healthcare provision. The duties of developed countries to put efforts into addressing their problems, in relation to the efforts put into research on ageing, requires consideration'.

The Council points out that 'Biomedical interventions, along with environmental, social and lifestyle modifications have already contributed to the extension of the human lifespan', but they cannot establish the relative importance of these influences. They recognize that some believe that focussing on medical treatments for ageing is unhelpful, in that it suggests ageing is a problem that requires fixing and reinforces negative views of ageing, sidelining 'other important elements of successful ageing, such as personal relationships, social position, physical environment and independence'. They comment that the WHO 'recommends that a holistic policy framework for healthy ageing should include a combination of public health measures, capacity building strategies and the creation of an age-friendly world'. The Note concludes that, in general, it is still 'not known whether biomedical ageing interventions will simply put off the period of ill-health or if this period will be extended, with people living longer in poor health'.

\section{Conclusion}

Where medical interventions can increase the length of healthy life they should obviously be encouraged. They should complement social, cultural and attitudinal change- increasing equality, ending discrimination and negative expectations about older people- non-medical interventions which can also help restore older people to a fitter, more active state. It is highly desirable for researchers in biomedical science, social science and the humanities to work together to deepen understanding of these issues.

Received: 15 March 2018 Accepted: 18 April 2018

Published online: 22 May 2018

\footnotetext{
Notes

1 Office of National Statistics (ONS). Statistical Bulletin. Estimates of the Very Old (including Centenarians), 2002-2016. http://www.ons.gov.uk/ peoplepopulationandcommunity/birthsdeathsandmarriages/ageing/bulletin/ estimatesoftheveryoldincludingcentenarians/2006to2016

2 Office of National Statistics. Statistical Bulletin. Health state life Expectancies, UK, 2014-2016. http://www.ons.gov.uk/peoplepopulationandcommunities/ healthandsocialcare/healthandlifeexpectancies/bulletins/ healthstatelifeexpectanciesUK/2014to2016\#healthy-life-expectany-at-birth
}

3 https://www.ageuk.org.uk/search/?q=Poverty-and-financial-disadvantage. Accessed 2 Mar 2018.

4 Marmot M. The Marmot Review: Fair Society, Healthy Lives. Strategic Review of Health Inequalities in England. http://www.marmotreview.org

5 http://www.webarchive.nationalarchives/gov/uk/20120919133219/http://www. communities.gov.uk/documents/communities/research/citizenshipsurvey.

6 WRVS (Women's Royal Voluntary Service, now RVS) 2011 Gold Age Pensioners. Valuing the social and economic contributions of older people in the UK https://www royalvoluntaryservice.org.uk/Documents/ gold-age-report-2011.pdf. Accessed 3 Mar 2018.

7 See footnote 2 .

8 Department of Health. Implementing a Ban on Age Discrimination in the NHS. Making effective, appropriate decisions, 2012. https:/www.gov.uk/government/ uploads/system/uploads/attachment_data/file/212944/ban-on-age-discrimination.pdf. Accessed 3 Mar 2018.

9 Nuffield Council on Bioethics Bioethics Briefing Note. The Search for a Treatment for Ageing, (London, 2018). www.nuffieldbioethics.org

\section{References}

Burke L (2017) Imagining a future without dementia: fictions of regeneration and the crises of work and sustainability. Pal Commun. 3(52) https://doi.org/ $10.1057 /$ s41599-017-0051-y

Clark J (2017) Clever ministrations: regenerative beauty at the fin de siècle. Pal Commun 3(47) https://doi.org/10.1057/s41599-017-0029-9

Edwards J, Thomas R, Guilliatt R (2017) Regenerative medicine: from the laboratory looking out. Pal Commun 3(27) https://doi.org/10.1057/s41599017-0036-x

Finlay M (1984) The elderly in classical antiquity. Ageing Soc 4/4:391-408

Gilleard C (2017) Regeneration, restoration and resurrection: scholastic inquiries into the nature of bodily growth and decay. Pal Commun 3(26) https://doi org/10.1057/s41599-017-0026-Z

Grundy E (2005) Reciprocity in relationships: socio-economic and health influences on intergenerational exchanges between third age parents and their adult children in Great Britain. Br J Sociol 55(2005):233-255

Logan C (2017) Psychoneurosis beyond Oedipus: neurophysiology, drive conflict, and the resolution of emotional trauma. Pal Commun 3(22) https://doi.org/ $10.1057 / \mathrm{s} 41599-017-0025-0$

Parkin T (2003) Old Age in the Roman World. A Cultural and Social History. The Johns Hopkins University Press, Baltimore, MD, USA

Shahar S (1997) Growing old in the middle ages. Routledge, London

Thane P (1990) The debate on the declining birth-rate in Britain: the menace of an ageing population, 1930s-1950s. Contin Chang 5(2):283-305

Wrigley EA, Davies RS, Oeppen JE, Schofield RS (1997) English population history from family reconstitution. Cambridge University Press, Cambridge, UK

\section{Additional information}

Competing interests: The author declares no competing interests.

Reprints and permission information is available online at http://www.nature.com/ reprints

Publisher's note: Springer Nature remains neutral with regard to jurisdictional claims in published maps and institutional affiliations.

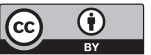

Open Access This article is licensed under a Creative Commons Attribution 4.0 International License, which permits use, sharing, adaptation, distribution and reproduction in any medium or format, as long as you give appropriate credit to the original author(s) and the source, provide a link to the Creative Commons license, and indicate if changes were made. The images or other third party material in this article are included in the article's Creative Commons license, unless indicated otherwise in a credit line to the material. If material is not included in the article's Creative Commons license and your intended use is not permitted by statutory regulation or exceeds the permitted use, you will need to obtain permission directly from the copyright holder. To view a copy of this license, visit http://creativecommons.org/ licenses/by/4.0/.

(C) The Author(s) 2018 